\title{
Antioxidant, alpha glucosidase and antibacterial evaluation of Syzygium mytifolium (Roxb.) Walp.
}

\author{
Mahmoud Dogara Abdulrahman \\ Department of Biology, Faculty of Education, Tishk International University, Erbil/Iraq \\ *Email: abdulrahman.mahmud@tiu.edu.iq
}

\section{ARTICLE HISTORY}

Received: 31 January 2021

Accepted: 08 April 2021

Published: 02 May 2021

\section{KEYWORDS}

Antioxidants

Antibiotics

Extract

Inhibition

Microorganisms
ABSTRACT

Medicinal plants have been the major source of combating and treating infectious diseases and health disorders throughout the ages. To explore new sources of inexpensive and safe antioxidants and antibiotics. The antioxidant and antibacterial potential of different extracts Syzygium mytifolium (Roxb.) Walp. were evaluated through 1,1-Diphenyl-2-Picryl Hydrazyl (DPPH), ferric reducing antioxidant power (FRAP), a-glucosidase inhibition, disk diffusion and agar well methods. The leaves, bark, root and whole plant of Syzygium mytifolium were extracted with various solvents viz ethanol, methanol and aqueous to give crude extracts, respectively. Among all, the ethanolic extract showed high antioxidant activity in terms of radical scavenging activity, reducing power and alpha-glucosidase inhibition at $1.84 \mu \mathrm{g} / \mathrm{ml}, 40.2 \mathrm{mmol} / \mathrm{gm}$ and $14.34 \mu \mathrm{g} / \mathrm{ml}$, respectively. All the tested parts of the plant exhibited moderate to higher range of antibacterial activity against bacterial pathogens with the inhibition zones ranged between 2-27.8 $\mathrm{mm}$. Syzygium mytifolium will serve as a very good source for the development of antioxidant supplements and antibiotics for addressing infectious pathogens and improvement of health status.

\section{Introduction}

Medicinal plants have been the major source of combating and treating infectious diseases and health disorders throughout the ages (1). Medicinal plants used in folk medicine provides a significant contributions to health improvement all over the world. Plants are still playing a vital role in the health improvement of developed and developing countries (2). Most of modern medicines were derived from medicinal plants. Presently medicinal plants are gaining more attention due to the fact that medicines of plant origin are very effective (3).

Medicinal plants are reported to have less or no toxic effects (4). The presence of bioactive compounds in the plant parts has made medicinal plants a valuable resource all over the world (5). Medicinal plants have been the principal guide in improving and curing man health (6). The abundance of secondary metabolites is found in plant parts with divergent promising activity against infection or improving human health (7). Secondary metabolites occur in different forms and functions depending on the plant
(8). As a result of urbanization, it is of paramount importance, medicinal plant documentation should be treated as a matter of urgency (9).

Today pathogenic microorganisms are constantly developing drug resistance towards numerous drugs or antibiotics that are constantly used to overcome their challenges in the human body (10). Utilization of whole plant and plant parts to treat various ailments has long been in practice all over the world both in developing and developed countries through the traditional medicinal system (11). Due to many problems associated with the resistance of microbes toward the antibiotics, the present day medicine has led to much interest on plants with promising traditional history (12). Medicinal plants constitute thousands of valuable compounds with therapeutic potentials (13). The usefulness of ethnobotany can only be emphasized if there is standardized in vitro and in vivo methods that can validate traditional herbalist claim (12).

The family Myrtaceae comprises of shrubs and trees in the pantropical region. There are about 142

(c) Abdulrahman (2021). This is an open-access article distributed under the terms of the Creative Commons Attribution License, which permits unrestricted use, distribution and reproduction in any medium, provided the original author and source are credited (https://creativecommons.org/licenses/by/4.0/)

To cite this article: Abdulrahman M D. Antioxidant, alpha glucosidase, and antibacterial evaluation of Syzygium mytifolium. Plant Science Today. 2021;8(2):410-415. https://doi.org/10.14719/pst.2021.8.2.1113 
genera with 17 tribes and 2 subfamily (14). The genus Syzygium is evergreen and densely foliaceous with thick bark. Their leaves are oblong ovate or obovate elliptic shape with 6 to $12 \mathrm{~cm}$. Wide variation exists in their shapes, due to the presence and absence of primary, secondary and tertiary vein in some species. Fruits range from 0.4 to $3.6 \mathrm{~cm}$ long, oblong in shape; edible. It is known to be very rich in antioxidants. The diversity and its morphological variation leads to hazardous task for drug discovery from the plants in general. Therefore, authentication of each medicinal plant is necessary. The present research deals with the evaluation of Syzygium mytifolium based on antioxidant, a-glucosidase inhibition and antibacterial activity. The selection of the pathogenic organisms were based on their potentials to cause diseases and food contamination.

\section{Materials and Methods}

\section{Taxonomic Identification}

Taxonomic identification and herbarium deposition, were made by a botanist (Professor Dr Nashriyah Mat) at the University Sultan Zainal Abidin (UniSZA), and finally deposited at Unisza, ABD 0087.

\section{Sample Collection and Extraction}

Plant parts were collected in Besut Terengganu state, Peninsular Malaysia from the wild at the same time to avoid any discrepancies in the bioactive compounds. Plants parts (leaves, bark, root and whole plant) collected from Syzygium mytifolium were washed in tap water and shade dried. The completely dried samples were grinded and $100 \mathrm{gm}$ of each powdered samples of each were carried out for Soxhlet extraction using ethanol, methanol and aqueous solvents. The extracts were filtered through Whatman filter no. 2 and the solvents are evaporated using Rotary evaporator (15).

\section{Yield of Extract $=$}

Dried extract (gm) / weight of dried material (gm) x 100

\section{1,1-Diphenyl-2-Picryl Hydrazyl (DPPH) Radical Scavenging Activity}

$200 \mu \mathrm{l}$ of DPPH methanolic solution $(0.004 \% \mathrm{w} / \mathrm{v})$ was added to $100 \mu \mathrm{l}$ of leaves, bark, root and whole plant (ethanolic, methanolic and aqueous) at 1.56, 3.13, $6.25,12.5,25,50$ and $100 \mu \mathrm{g} / \mathrm{ml}$ concentration respectively. The solution was kept at the dark for 30 min at room temperature. DPPH reduction was recorded at $517 \mathrm{~nm}$. The scavenging percentage activity was evaluated by comparing the control (200 $\mu \mathrm{l}$ DPPH +100 $\mu \mathrm{l}$ methanol). Quercetin was used as reference standards (16). The radical scavenging activity was calculated using the formula:

$$
\text { Inhibition }(\%)=[(\text { Ao-A1 }) / \text { Ao })] \times 100
$$

Where, Ao is the control absorbance reaction and A1 is the sample absorbance.

\section{Ferric Reducing Antioxidant Power (FRAP) Assay}

A working FRAP solution was prepared by mixing $300 \mathrm{mM}$ acetate buffer, $10 \mathrm{mM}$ (2,4,6-tri (2-Pyridyl) -Striazine) $\mathrm{TPTZ}$ in $40 \mathrm{mM} \mathrm{HCl}$ and $20 \mathrm{mM} \mathrm{FeCl}_{3}$ in the ratio of $10: 1: 1$ and warmed at $37^{\circ} \mathrm{C}$ for $10 \mathrm{~min}$ in a water bath before use. A $285 \mu$ l of the working FRAP solution was added to $15 \mu \mathrm{l}$ of plant samples (ethanolic, methanolic and aqueous) of $100 \mu \mathrm{g} / \mathrm{ml}$ respectively and incubated at room temperature in the dark for $30 \mathrm{~min}$. Absorbance was read at $517 \mathrm{~nm}$. FeSO4.7 $\mathrm{H}_{2} \mathrm{O}$ with concentration between 125 to 1000 $\mu \mathrm{M}$ was used as a standard and the results were expressed as micromoles of $\mathrm{Fe}^{2+}$ equivalents per gram of dried extract mmol $\mathrm{Fe}^{2+} / \mathrm{gm}$ (17).

\section{a-glucosidase Inhibition Assay}

The alpha glucosidase method was performed with the following conditions. A $10 \mu \mathrm{l}$ of extracts from leaves, bark, root and whole plant samples at $0,1.56$, $3.13,6.25,12.5,25,50$ and $100 \mu \mathrm{g} / \mathrm{ml}$ were mixed with $50 \mu \mathrm{l}$ of $0.1 \mathrm{M}$ phosphate buffer ( $\mathrm{pH} 7.0), 25 \mu \mathrm{l}$ of alpha-glucosidase in buffer $(0.2 \mathrm{U} / \mathrm{ml})$ were added into well plate and incubated for 10 minutes at $37^{\circ} \mathrm{C}$ to initiate the reaction. A $25 \mu \mathrm{l}$ of $0.5 \mathrm{mM} 4$ nitrophenyl alpha-D-glucopyranoside (pNPG) substrate was added to complete the reaction and incubated for another $30 \mathrm{~min}$ at $37^{\circ} \mathrm{C}$. The reaction was terminated by adding $100 \mu \mathrm{l}$ of $0.2 \mathrm{M}$ sodium carbonate solution. Quercetin was used as positive control (17). The absorbance was measured at 410 $\mathrm{nm}$. The percentage of inhibition was calculated using the following formula: The Percentage of inhibition was calculated using the following formula:

Inhibition (\%) [Control abs - sample abs)/control abs] x 100

\section{Antibacterial Activity}

\section{Sample preparation}

Stock solutions of leaves, bark, root and whole plant (ethanolic, methanolic and aqueous) extracts 10000 $\mu \mathrm{g} / \mathrm{ml}$ was prepared in DMSO, the following concentrations were prepared from the stock solutions 1000, 2000 and $4000 \mu \mathrm{g} / \mathrm{ml}$ respectively.

\section{Media preparation}

Mueller Hinton Agar (MHA) and Mueller Hinton Broth (MHB) was prepared according to the manufacturer instruction; it was autoclaved at $121{ }^{\circ} \mathrm{C}$ cooled to room temperature and poured in to the sterile disposable Petridish under aseptic conditions. The plates were stored at $4^{\circ} \mathrm{C}$ before use (1).

\section{Test Microorganisms}

Gram negative: Escherichia coli (ATCC 33591), Klebsiella pneumoniae (ATCC 700603), Salmonella typhi (ATCC 14028), Enterobacter (ATCC 13048), Pseudomonas aeruginosa (ATCC 27853) and Gram positive: Staphylococcus aureus (ATCC 33591), Enterococcus faecalis (ATCC 24212), Listeria monocytogenes (ATCC 7644), Bacillus (ATCC 14579) and Staphylococcus epidermidis (ATCC 12228) bacteria were provided by the microbiology department of Universiti sultan Zainal Abidin (UniSZA) respectively. Microbial stock culture using inoculation loop were streak on Mueller Hinton agar plates and incubated at $37{ }^{\circ} \mathrm{C}$ for overnight. The following day, they were subculture until a fresh colony was obtained and inoculated on Mueller Hinton broth and incubate overnight at $200 \mathrm{rpm}(18,19)$. 
Table 1. Percentage of yield extracts from ethanolic, methanolic and aqueous extracts from the leaves, bark, root and whole plants of Syzygium mytifolium.

\begin{tabular}{ccc}
\hline Plants parts & Extracts & $\begin{array}{c}\text { Extraction yields } \\
\text { (\%) }\end{array}$ \\
\hline SML & Ethanol & $16.5^{\mathrm{a}}$ \\
\hline SMB & Ethanol & $15.7^{\mathrm{a}}$ \\
\hline SMR & Ethanol & $11.3^{\mathrm{b}}$ \\
\hline SMW & Ethanol & $17.1^{\mathrm{a}}$ \\
\hline SML & Aqueous & $4.5^{\mathrm{f}}$ \\
\hline SMB & Aqueous & $5.3^{\mathrm{e}}$ \\
\hline SMR & Aqueous & $3.4^{\mathrm{fg}}$ \\
\hline SMW & Aqueous & $2.4^{\mathrm{g}}$ \\
\hline SML & Methanol & $9.9^{\mathrm{bc}}$ \\
\hline SMB & Methanol & $11.1^{\mathrm{b}}$ \\
\hline SMR & Methanol & $8.7^{\mathrm{cd}}$ \\
\hline SMW & Methanol & $7.6^{\mathrm{de}}$
\end{tabular}

Note: Values are the Means \pm Standard deviation of three replicates of three different experiment. Values with same alphabet have no significant difference at $\mathrm{p} \leq 0.05$. SML $=$ Syzygium mytifolium Leaves, SMB = Syzygium mytifolium Bark, SMR = Syzygium mytifolium Root, SMW = Syzygium mytifolium Whole plant.

Table 2. Percentage of inhibition and $\mathrm{IC}_{50}$ value of ethanolic, methanolic and aqueous extracts from the leaves, bark, root and whole plants of Syzygium mytifolium on radical scavenging activity (DPPH) at concentration $100 \mu \mathrm{g} / \mathrm{ml}$.

\begin{tabular}{lcc}
\hline \multicolumn{1}{c}{ Sample } & $\begin{array}{c}\text { Percentage of } \\
\text { inhibition }\end{array}$ & $\begin{array}{c}\mathbf{I C}_{50} \text { Value } \\
(\boldsymbol{\mu g} / \mathbf{m l})\end{array}$ \\
\hline Syzygium mytifolium $L E$ & $89.94 \pm 0.1$ & $1.84^{\mathrm{j}}$ \\
\hline Syzygium mytifolium $B E$ & $86.33 \pm 1.1$ & $9.54^{\mathrm{f}}$ \\
\hline Syzygium mytifolium $R E$ & $83.91 \pm 0.7$ & $9.92^{\mathrm{d}}$ \\
\hline Syzygium mytifolium $W E$ & $86.85 \pm 0.3$ & $3.39^{\mathrm{i}}$ \\
\hline Syzygium mytifolium $L M$ & $88.25 \pm 0.1$ & $1.84^{\mathrm{j}}$ \\
\hline Syzygium mytifolium $B M$ & $85.64 \pm 0.3$ & $3.71^{\mathrm{h}}$ \\
\hline Syzygium mytifolium $R M$ & $86.82 \pm 0.1$ & $11.00^{\mathrm{c}}$ \\
\hline Syzygium mytifolium $W M$ & $86.33 \pm 0.4$ & $9.63^{\mathrm{e}}$ \\
\hline Syzygium mytifolium $L A$ & $87.59 \pm 0.2$ & $30.31^{\mathrm{a}}$ \\
\hline Syzygium mytifolium $B A$ & $82.31 \pm 0.1$ & $22.90^{\mathrm{b}}$ \\
\hline Syzygium mytifolium $R A$ & $87.02 \pm 0.1$ & $8.31^{\mathrm{g}}$ \\
\hline Syzygium mytifolium $W A$ & $85.64 \pm 0.3$ & $3.71^{\mathrm{h}}$ \\
\hline Quercetin & $89.77 \pm 0.1$ & $1.84^{\mathrm{j}}$ \\
\hline
\end{tabular}

Note: Values are the Means \pm Standard deviation of three replicates of three different experiment. Values with same alphabet have no significant difference at $\mathrm{p} \leq 0.05$. L $\mathrm{E}=$ Leaves Ethanolic, B E = Bark Ethanolic, R E = Root Ethanolic, $\mathrm{L} \mathrm{M}=$ Leaves Methanolic, $\mathrm{B} \mathrm{M}=$ BARK Methanolic, $\mathrm{R} \mathrm{M}=$ Root Methanolic, W M $=$ Whole plant Methanolic, $\mathrm{L} \mathrm{A}=$ Leaves Aqueous, $\mathrm{B} \mathrm{A}=$ Bark Aqueous, $\mathrm{R} \mathrm{A}=$ Root A=Aqueous, $\mathrm{W}$ A = Whole plant Aqueous.

\section{Disk Diffusion Method}

Solidified mueller hinton plates was seeded with 200 $\mu \mathrm{l}$ of microbial inoculums $1.10^{6}$ (CFU) $\mathrm{ml}^{-1}$. A whatman no 1 filter paper discs $(6 \mathrm{~mm})$ were impregnated with $20 \mu \mathrm{l}$ of different concentrations of 1000,2000 and $4000 \mu \mathrm{g} / \mathrm{ml}$ of the plant parts (ethanolic, methanolic and aqueous) extract. The impregnated disc was placed with the aid of sterile forceps on the plates. Plates were incubated at $37{ }^{\circ} \mathrm{C}$ for $24 \mathrm{hr}$. Zone of inhibition was recorded in triplicate (20).

\section{Agar Well Diffusion Method}

Mueller Hinton agar seeded was inoculated with 200 $\mu \mathrm{l}$ microbial loads of $1.10^{6}$ (CFU) $\mathrm{ml}^{-1}$. The plates divide into five equal quadrants and a well of $6 \mathrm{~mm}$ were cut using a sterile cork borer. A $100 \mu \mathrm{l}$ of different concentrations of 1000, 2000 and $4000 \mu \mathrm{g} / \mathrm{ml}$ of the above mentioned plants parts were introduced into the well and incubated for $24 \mathrm{hr}$ at $37{ }^{\circ} \mathrm{C}$. All experiment was carried out in triplicate of three different time and measured the zone of inhibition using ruler in millimeter (21).

\section{Statistical Analysis}

The data was analyzed using Statistical Analysis System (SAS) software (University version 9.4). Completed Randomized Design (CRD) was employed as the experimental design with three replication. One way repeated ANOVA procedure was carried out and means were subjected to post hoc Duncan's Multiple Range Test (DMRT) to find out significant differences in the means at $\mathrm{p} \leq 0.05$ level.

\section{Results}

Higher yield was recorded from the ethanolic extracts of the whole plant (17.1\%). It was followed by the ethanolic leaves extracts (16.5\%) and low yield was recorded from the aqueous whole plant extracts $(2.4 \%)$ as shown in (Table 1$)$. The result obtained showed significant difference among the treatment.

\section{DPPH Free Radical}

Radical scavenging activities of DPPH was determined on the leaves, bark, root and whole plants of ethanolic, methanolic and aqueous extracts of Syzygium mytifolium. The highest scavenging activities were recorded from the ethanolic leaf extract with $\mathrm{IC}_{50}$ value of 1.84 and the least was recorded from the aqueous leaves extracts at 30.31 $\mu \mathrm{g} / \mathrm{ml}$ respectively (Table 2 ). The result obtained showed a significant difference among the treatment.

\section{FRAP Assay}

Whole plant and root ethanolic extract was found to have the highest ability to converting $\mathrm{Fe}^{3+}$ to $\mathrm{Fe}^{2+}$ with 40.2 and $39.5 \mathrm{mmol} / \mathrm{gm}$ respectively, then methanolic whole plant extract $38.8 \mathrm{mmol} / \mathrm{gm}$. The result obtained show a significant difference among the treatment (Table 3).

Table 3. $\mathrm{Fe}^{2+} /(\mathrm{mmol} / \mathrm{gm})$ formed from the ethanolic, methanolic and aqueous extract of the leaves, bark, root and whole plants of Syzygium mytifolium

\begin{tabular}{lc}
\hline Sample & Percentage of inhibition \\
\hline Syzygium mytifolium $L E$ & $26.57 \mathrm{~g}$ \\
\hline Syzygium mytifolium $B E$ & $6.8 \mathrm{~m}$ \\
\hline Syzygium mytifolium $R E$ & $39.5 \mathrm{c}$ \\
\hline Syzygium mytifolium $W E$ & $40.2 \mathrm{~b}$ \\
\hline Syzygium mytifolium $L A$ & $9.8 \mathrm{k}$ \\
\hline Syzygium mytifolium $B A$ & $57.9 \mathrm{a}$ \\
\hline Syzygium mytifolium $R A$ & $39.1 \mathrm{~d}$ \\
\hline Syzygium mytifolium $W A$ & $22.7 \mathrm{~h}$ \\
\hline Syzygium mytifolium $L M$ & 6.91 \\
\hline Syzygium mytifolium $B M$ & $17.9 \mathrm{j}$ \\
\hline Syzygium mytifolium $R M$ & $21.3 \mathrm{i}$ \\
\hline Syzygium mytifolium $W M$ & $38.8 \mathrm{e}$ \\
\hline Quercetin & $27.03 \mathrm{f}$
\end{tabular}

Note: Values are the Means \pm Standard deviation of three replicates of three different experiment. Values with same alphabet have no significant difference at $\mathrm{p} \leq 0.05$. $\mathrm{L} \mathrm{E}=$ Leaves Ethanolic, $\mathrm{B} \mathrm{E}=$ Bark Ethanolic, $\mathrm{R} \mathrm{E}=$ Root Ethanolic, $\mathrm{L} \mathrm{M}=$ Leaves Methanolic, $\mathrm{B} \mathrm{M}=$ BARK Methanolic, $\mathrm{R} \mathrm{M}=$ Root Methanolic, $\mathrm{W} \mathrm{M}=$ Whole plant Methanolic, $\mathrm{L} \mathrm{A}=$ Leaves Aqueous, $\mathrm{B} \mathrm{A}=$ Bark Aqueous, R A = Root Aqueous, $\mathrm{W}$ A = Whole plant Aqueous. 
Table 4. Percentage of inhibition and $\mathrm{IC}_{50}$ Value of ethanolic, methanolic and aqueous extracts from the leaves, bark, root and whole plants of Syzygium mytifolium against a-glucosidase at concentration $100 \mu \mathrm{g} / \mathrm{ml}$.

\begin{tabular}{lcc}
\hline \multicolumn{1}{c}{ Sample } & $\begin{array}{c}\text { Percentage } \\
\text { of inhibition }\end{array}$ & $\begin{array}{c}\mathbf{I C}_{\mathbf{5 0}} \text { Value } \\
(\boldsymbol{\mu g} / \mathbf{m L})\end{array}$ \\
\hline Syzygium mytifolium $L E$ & $67.33 \pm 0.4$ & $20.36^{\mathrm{i}}$ \\
\hline Syzygium mytifolium $B E$ & $67.89 \pm 0.6$ & $46.95^{\mathrm{f}}$ \\
\hline Syzygium mytifolium $R E$ & $58.98 \pm 0.1$ & $73.78^{\mathrm{b}}$ \\
\hline Syzygium mytifolium $W E$ & $62.70 \pm 0.1$ & $14.34^{\mathrm{j}}$ \\
\hline Syzygium mytifolium $L M$ & $87.53 \pm 0.2$ & $58.96^{\mathrm{e}}$ \\
\hline Syzygium mytifolium $B M$ & $57.77 \pm 0.3$ & $25.54^{\mathrm{h}}$ \\
\hline Syzygium mytifolium $R M$ & $45.07 \pm 0.1$ & $60.5^{\mathrm{d}}$ \\
\hline Syzygium mytifolium $W M$ & $88.53 \pm 0.3$ & $\mathrm{ND}^{\mathrm{n}} M$ \\
\hline Syzygium mytifolium $L A$ & $87.03 \pm 0.1$ & $\mathrm{ND}^{\mathrm{c}}$ \\
\hline Syzygium mytifolium $B A$ & $71.81 \pm 0.2$ & $69.69^{\mathrm{c}}$ \\
\hline Syzygium mytifolium $R A$ & $74.55 \pm 0.2$ & $81.45^{\mathrm{a}}$ \\
\hline Syzygium mytifolium $W A$ & $87.31 \pm 0.1$ & $\mathrm{ND}^{\mathrm{g}}$ \\
\hline Quercetin & $59.1 \pm 0.4$ & $30.12^{\mathrm{g}}$ \\
\hline
\end{tabular}

Note: Values are the Means \pm Standard deviation of three replicates of three different experiment. Values with same alphabet have no significant difference at $\mathrm{p} \leq 0.05$. $\mathrm{L} E=$ Leaves Ethanolic, B E = Bark Ethanolic, $\mathrm{R} \mathrm{E}=$ Root Ethanolic, $\mathrm{L} \mathrm{M}=$ Leaves Methanolic, $\mathrm{B} \mathrm{M}=$ BARK Methanolic, $\mathrm{R} \mathrm{M}=$ Root Methanolic, $\mathrm{W} \mathrm{M}=$ Whole plant Methanolic, $\mathrm{L} \mathrm{A}=$ Leaves Aqueous, $\mathrm{B} \mathrm{A}=\mathrm{Bark}$ Aqueous, $\mathrm{R} \mathrm{A}=$ Root $\mathrm{A}=$ Aqueous, $\mathrm{W} \mathrm{A}=$ Whole plant Aqueous $\mathrm{ND}=$ No Activity Detected.

\section{a-glucosidase Inhibition}

The a-glucoside inhibitory activity of the ethanolic, methanolic and aqueous extracts of the above plant parts were investigated using $100 \mu \mathrm{g} / \mathrm{ml}$ sample. The percentage inhibition and the inhibition concentration at $50\left(\mathrm{IC}_{50}\right)$ were calculated Table 4 revealed the ethanolic the whole plants ethanolic extracts has the highest $\mathrm{IC}_{50}$ Value $14.34 \mu \mathrm{g} / \mathrm{ml}$ exhibited the best a-glucoside inhibition as compared to all other part and control (Quercetin). The $\mathrm{IC}_{50}$ values were not detected in the whole plant methanolic and aqueous leaves extract respectively (Table 4). The result obtained shows a significant difference among the treatment.

\section{Antibacterial Screening}

Disk diffusion method was used to test Gram positive and Gram negative bacteria (Five strains each) from the ethanolic, methanolic and aqueous extract of leaves, bark, root and whole plant at three different concentrations of 1000, 2000 and $4000 \mu \mathrm{g} / \mathrm{ml}$, respectively. All the tested part has shown a significant zone of inhibition (2-27.8 $\mathrm{mm})$ (Supplementary Table 1 and 2). Similarly, agar well method was used against the five strains of Gram positive and Gram negative bacteria using the same concentrations of 1000, 2000 and $4000 \mu \mathrm{g} / \mathrm{ml}$ respectively to further evaluate and validate the disk diffusion method. All the tested parts showed a significant zone of inhibition against the tested strains (2-27.8 mm). (Supplementary Table 3 and 4). Except for the aqueous extract which has little or no inhibition against the tested pathogens.

\section{Discussion}

The present study revealed the antioxidants and the antibacterial activity of ethanol, methanol and aqueous extracts against the DPPH, FRAP and the tested infectious microorganisms. The differences are due to the presence of phenolics, saponins, terpenoids, flavonoids, phenol, alkaloids and tannins compound. Previously it has been reported phenolic compound to be the most occurring phytochemical compound that exhibited antioxidants and infectious microorganisms (22). The present study evaluated the ethanolic, methanolic and aqueous extracts Syzygium mytifolium against the antioxidant and antibacterial potential of the plants against some infectious Gram positive and Gram negative pathogens. Some of these pathogens were known to cause skin infection, typhoid, systemic infection and food spoilage (23) Many reasons resulted the utilization of medicinal plants by humans all over the world. This is due to the health improvement after utilization of the plant parts (24). As a result of the persistence of pathogenic resistance to the available antibiotics search for new is unabated. Plants remain the only alternative to therapeutic drugs (25).

Today, a significant number of synthetic drugs are produced from plant material. The disparity in the extract yield of the plant parts is strongly dependent on the type of nature of extraction solvents, extraction, nature of compounds presents, and the polarity of the metabolites present in the extract (26). For the purpose of antioxidant evaluation DPPH and FRAP method were adopted (27, 28). In this study, S. mytifolium was found to be very good source of antioxidant against free radicals produce in human body. The established activity of the extracts from the different parts of the plant was due to the present of some compound such as the methoxyl group, hydroxyl group, flavonoids compound, phenolics compounds that might be present in each of the extract (29). Alpha glucosidase is the main enzyme responsible for catalyzing the digestive end process of carbohydrates (30). The moderate activity of a-glucosidase inhibition was reported from the different plant parts. The results are in agreement with (1) where they report a high activity on a-glucosidase of Syzygium polyanthum extracts. The high activity of the ethanolic and methanolic extract against the aqueous extract might be due to the fact the solvent extract more secondary metabolite compound as against the aqueous. The preliminary antibacterial evaluation revealed the plants parts appear to have broad spectrum actions against all the tested microorganisms except for the aqueous extraction which has little or no activity. The present study revealed the activity of the plant parts varies with the solvents and the parts of the plant examined. Therefore, the utilization of different solvents and concentrations in the evaluation of the biological activity of the plants is of paramount importance. Because this will elucidate the novel metabolites in the plant (31). Similarly, report in the antibacterial preliminary evaluation of some selected medicinal plants: that different solvents stand to reveal different metabolites.

\section{Conclusion}

The establishment of the large spectra of the Syzygium mytifolium against free radical inhibition, alpha glucosidase inhibition and antibacterial 
activity. This will be a very good source for the development of herbal supplements and antibiotics for addressing infectious pathogens and improvement of health status.

\section{Acknowledgements}

The author wish to acknowledge the support of Universiti Sultan Zainal Abidin Malaysia and Tishk International University, Erbil Iraq.

\section{Conflict of interests}

Author do not have any conflict of interests to declare.

\section{Supplementary files}

Table 1. Disk diffusion antibacterial evaluation of ethanolic, methanolic and aqueous extracts of leaves, bark, root and whole plant of Syzygium mytifolium against Gram positive bacteria

Table 2. Disk diffusion antibacterial evaluation of ethanolic, methanolic and aqueous extracts of leaves, bark, root and whole plant of Syzygium mytifolium against Gram negative bacteria

Table 3. Ager well antibacterial evaluation of ethanolic, methanolic and aqueous extracts of leaves, bark, root and whole plant of Syzygium mytifolium against Gram positive bacteria

Table 4. Ager well antibacterial evaluation of ethanolic, methanolic and aqueous extracts of leaves, bark, root and whole plant of Syzygium mytifolium against Gram negative bacteria

\section{References}

1. Abdulrahman MD, Ali AM, Fatihah H, Khandaker MM, Mat N. In vitro biological investigations on Syzygium polyanthum cultivars. Int J Agric Biol. 2019; 22(6):1399-1406.

2. Mahmoud AD, Labaran I, Yunusa A, Ethnobotany of medicinal plants with antimalarial potential in Northern Nigeria. Ethnobotany Research and Applications. 2020.19:1-8. https://doi.org/10.32859/era.19.32.1-8

3. Gurib-Fakim A, Medicinal plants: traditions of yesterday and drugs of tomorrow. Molecular Aspects of Medicine. 2006;27(1):1-93. https://doi.org/10.1016/i.mam.2005.07.008

4. George P. Concerns regarding the safety and toxicity of medicinal plants-An overview. Journal of Applied Pharmaceutical Science. 2011;1(6):40-44.

5. Patra JK, Das G, Lee S, Kang SS, Shin H S. Selected commercial plants: A review of extraction and isolation of bioactive compounds and their pharmacological market value. Trends $\begin{array}{lll}\text { Food Sci } & \text { Tech. } & \text { 2018;82:89-109. }\end{array}$ https://doi.org/10.1016/ị.tifs.2018.10.001

6. Kumar B, Vijayakumar M, Govindarajan R, Pushpangadan P. Ethnopharmacological approaches to wound healingexploring medicinal plants of India. J Ethnopharmacol. 2007;114(2):103-13. https://doi.org/10.1016/j.jep.2007.08.010

7. Lelario F, Scrano L, De Franchi S, Bonomo M, Salzano G, Milan $S$, Bufo S. Identification and antimicrobial activity of most representative secondary metabolites from different plant species. Chemical and Biological Technologies in Agriculture. 2018;5(1):1-12. https://doi.org/10.1186/s40538-018-0125-0
8. Zhao J, Davis LC, Verpoorte R. Elicitor signal transduction leading to production of plant secondary metabolites. Biotechnology Advances. 2005;23(4):283-333. https://doi.org/10.1016/i.biotechadv.2005.01.003

9. Sivasankari B, Anandharaj MP. Gunasekaran. An ethnobotanical study of indigenous knowledge on medicinal plants used by the village peoples of Thoppampatti, Dindigul district, Tamil Nadu, India. J Ethnopharmacology. 2014;153(2): 408-23. https://doi.org/10.1016/j.jep.2014.02.040

10. Ramli S, Radu S, Shaari K, Rukayadi Y. Antibacterial activity of ethanolic extract of Syzygium polyanthum L. (Salam) leaves against foodborne pathogens and application as food sanitizer. BioMed Research International. 2017;17-24. https://doi.org/10.1155/2017/9024246

11. Jaberian H, Piri K, Nazari J. Phytochemical composition and in vitro antimicrobial and antioxidant activities of some medicinal plants. Food Chem. 2013;136(1):237-44. https://doi.org/10.1016/j.foodchem.2012.07.084

12. Abdulrahman MD, Ali AM, Fatihah H, Khandaker MM, Mat N Traditional medicinal knowledge of Malays in Terengganu, Peninsular Malaysia. Malayan Nature Journal. 2018;70(3):34964 .

13. Akram M, Tahir I M, Shah SMA, Mahmood Z, Altaf A, Ahmad K, Mehboob $\mathrm{H}$. Antiviral potential of medicinal plants against HIV, HSV, influenza, hepatitis and coxsackievirus: a systematic review. Phytotherapy Research. 2018;32(5):811-22. https://doi.org/10.1002/ptr.6024

14. Stefanello MÉA, Pascoal AC, Salvador MJ. Essential oils from neotropical Myrtaceae: chemical diversity and biological properties. Chem Biodivers. 2011.8(1):73-94. https://doi.org/10.1002/cbdv.201000098

15. Li HB, Jiang Y, Wong CC, Cheng KW, Chen F. Evaluation of two methods for the extraction of antioxidants from medicinal $\begin{array}{llll}\text { plants. Anal } & \text { Bioanal. } 2007 . & 388(2): 483-88 .\end{array}$ https://doi.org/10.1007/s00216-007-1235-X

16. Yunusa AK, Rohin MAK, Bakar CAA. Free radical scavenging activity of polyphenols. Journal of Chemical and Pharmaceutical Research. 2015.7(3):1975-80.

17. Yunusaa AK. DPPH radical scavenging activitiy and total phenolic content of rambutan (Nephelium lappaceum) peel and seed. Ann Food Sci Technol. 2018;19:774-79.

18. Su Y, Sun J, Rao S, Cai Y, Yang Y. Photodynamic antimicrobial activity of hypocrellin A. Journal of Photochemistry and Photobiology B: Biology. 2011;103(1):29-34 https://doi.org/10.1016/i.jphotobiol.2011.01.008

19. Su PW, Yang CH, Yang JF, Su PY, Chuang LY. Antibacterial activities and antibacterial mechanism of Polygonum cuspidatum extracts against nosocomial drug-resistant pathogens. $\quad$ Molecules. 2015;20(6):11119-30 https://doi.org/10.3390/molecules200611119

20. Parekh J, Chanda S. In vitro antimicrobial activity and phytochemical analysis of some Indian medicinal plants. Turk J Biol. 2007;31(1):53-58.

21. Srinivasan D, Nathan, Suresh ST, Perumalsamy PL Antimicrobial activity of certain Indian medicinal plants used in folkloric medicine. J Ethnopharmacology. 2001;74(3):217-20. https://doi.org/10.1016/S0378-8741(00)00345-7

22. Chew YL, Chan EWL, Tan PL, Lim YY, Stanslas J, Goh JK. Assessment of phytochemical content, polyphenolic composition, antioxidant and antibacterial activities of Leguminosae medicinal plants in Peninsular Malaysia. BMC Complem Altern $\quad$ M. 2011;11(1):1-10 https://doi.org/10.1186/1472-6882-11-12

23. Friedman M. Overview of antibacterial, antitoxin, antiviral and antifungal activities of tea flavonoids and teas. Mol Nutr $\begin{array}{lll}\text { Food } & \text { Res. 2007;51(1):116-34 }\end{array}$ https://doi.org/10.1002/mnfr.200600173

24. Briskin DP. Medicinal plants and phytomedicines. Linking plant biochemistry and physiology to human health. Plant Physiol Plant. 2000;124(2):507-14. https://doi.org/10.1104/pp.124.2.507 
25. Ribeiro da Cunha B, Fonseca LP, Calado CR. Antibiotic discovery: where have we come from, where do we go? Antibiotics. 2019.8(2):45-51. https://doi.org/10.3390/antibiotics8020045

26. Sinha AK, Sharma UK, Sharma N. A comprehensive review on vanilla flavor: extraction, isolation and quantification of vanillin and others constituents. International Journal of Food $\begin{array}{lll}\text { Sciences and Nutrition. 2008;59(4):299-326. } & \text {. }\end{array}$ https://doi.org/10.1080/09687630701539350

27. Govindarajan R, Vijayakumar M, Pushpangadan P. Antioxidant approach to disease management and the role of 'Rasayana' herbs of Ayurveda. J Ethnopharmacology. 2005;99(2):165-78. https://doi.org/10.1016/i.jep.2005.02.035

28. Huang D, Ou B, Prior RL. The chemistry behind antioxidant capacity assays. J Agr Food Chem. 2005;53(6):1841-56. https://doi.org/10.1021/jif030723c
29. Heim KE, Tagliaferro AR, Bobilya DJ. Flavonoid antioxidants: chemistry, metabolism and structure-activity relationships. The Journal of Nutritional Biochemistry. 2002;13(10):572-84. https://doi.org/10.1016/S0955-2863(02)00208-5

30. Assefa ST, Yang EY, Chae SY, Song M, Lee J, Cho, M-C, Jang S. Alpha glucosidase inhibitory activities of plants with focus on common vegetables. Plants. 2020;9(1):2-11. https://doi.org/10.3390/plants9010002

31. Taye B, Giday M, Animut A, Seid J. Antibacterial activities of selected medicinal plants in traditional treatment of human wounds in Ethiopia. Asian Pac J Trop Med. 2011;1(5):370-75. https://doi.org/10.1016/S2221-1691(11)60082-8 